\title{
A FREQUENCY DETERMINATION METHOD FOR AUTOMOTIVE NANOSENSORS
}

\author{
Gurko A. G. ${ }^{1}$, Sergiyenko O. Yu. ${ }^{2}$ \\ ${ }^{1}$ Kharkiv National Automobile and Highway University \\ ${ }^{2}$ Autonomous University of Baja California
}

\begin{abstract}
The growing popularity of nanosensors in various automotive applications requires new methods for counting the frequency of electrical signals, into which the measured non-electrical parameters are converted. This need is because automobile nanosensors are to register very small changes in the measured parameters that, besides, can change very fast. The paper proposes for use in automotive nanosensors a frequency calculation method based on the principle of rational approximation, which meets the above requirements.
\end{abstract}

Key words: automotive nanosensors, frequency measurement, rational approximation.

\section{Introduction}

A modern automobile is a complex mechatronic system that includes mechanical and electronic components connected with a single sensor network $[1,2]$. A significant part of the promising and existing automotive sensors based on nanotechnology [3-5]. Nanosensors allow for the reduction of the size of the sensor at a lower cost.

On the other hand, nanosensors have some significant differences from traditional ones. First, the sensitivity threshold of nanosensors can be minuscule. Second, the values of the physical parameters measured by the sensors can change very fast. These factors cause some significant difficulties after converting the measured parameter to the frequency of the electrical signal, since the classical methods of frequency measuring [6] do not allow the frequency to be registered fast and accurately at the same time. Nevertheless, frequency-domain sensors are some of the most promising tools in metrology due to their high resolution and sensitivity, wide dynamic range and good stability [7]. Moreover, many physical parameters can be easily converted into the frequency of an electrical signal. Thus, frequency measurement methods are needed that meet all the requirements for use in automotive nanosensors.

\section{Review of the literature}

The first frequency counters used conventional counting when the number of input cycle trigger events occur during a fixed reference gate was counted $[8,9]$. Due to the simplicity of implementation, this method is still used. However, it is not suitable for low and medium frequencies.
The wide spreading of microcontrollers contributed to the using of reciprocal frequency counting [8-10]. In this method, the average cycle time $M T$ is first determined, over which $N$ input signal periods are registered. Then the mean frequency value is calculated:

$$
f_{x}=\frac{N}{M T} .
$$

Further evolution of frequency counting is associated with both the improvement of reciprocal counting and the development of new methods: continuous time-stamping method [8]; the dependent count [9]; methods, based on delay-chain technique $[11,12]$, and multiaverage frequency measurement principle [13].

There are some methods, provides for the conversion of an analogue sine signal to a digital signal which is then processed by any digital signal processing technology, for instance, based on Fast Fourier Transform [14, 15].

\section{Purpose and Problem Description}

The literature survey shows the presence of numerous frequency counting methods that are used to measure various non-electrical quantities. However, some of these methods are complicated or need expensive instruments, and some of them long time for data processing. This paper proposes to use the method for determining the signal frequency presented by the authors earlier [16-18] in modern automotive nanosensors to ensure the speed and accuracy of measurements.

The rest of the paper is organized as follows. The following section reviews the applications of automotive nanosensors and describes the design and principles of operation of some of 
them. Then, the main provisions of the method for determining the frequency are given, some examples are considered, and the accuracy of this method is analyzed. Finally, concluding remarks are given in the last section.

\section{Applications of nanosensors in automotive industry}

Recent advances in nanomaterials and nanotechnology have made them promising for automotive applications. Today nanotechnology is used in the production of lightweight and durable cars bodies, their components and assemblies, more resistant paints, antifriction layers, and antiwear additives, etc. [3, 4, 19-21]. The use of nanotechnology opens up tremendous opportunities in various automotive monitoring and control systems. It is well known that a modern automobile has a huge number of sensors [1, 22-26]. Their growing responsibilities are taken care of improving the performance, safety, and comfort aspects. All the variety of these sensors can be divided into the following groups (Fig. 1):

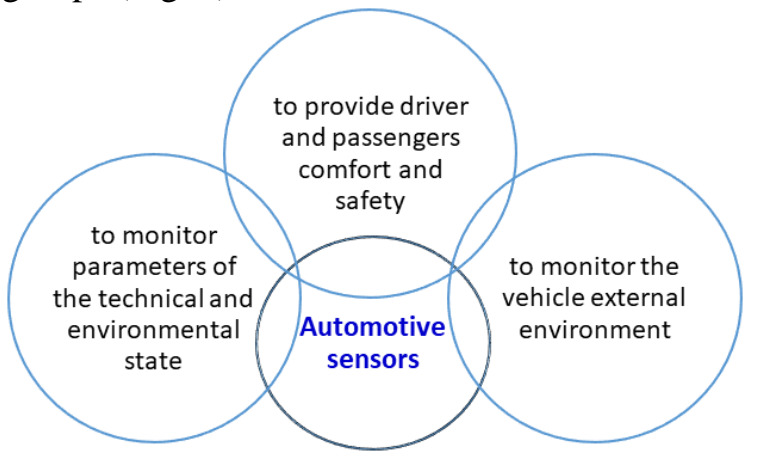

Fig. 1. Automotive sensors classification

i) to monitor various parameters of the technical and environmental state of the vehicle;

ii) for systems that provide driver/passengers comfort and safety;

iii) sensors for monitoring the vehicle external environment.

This classification is conditional since, for instance, sensors that monitor the external environment can be attributed to systems for improving driving safety, etc.

Further development of sensors for these applications is associated with the use of nanotechnology. Nanosensors offer at the same time several key attributes such as small size elements, low power consumption, fast response time, high sensitivity and selectivity.

A nanosensor is a measuring device that combines electronic and mechanical components, the size of which does not exceed $100 \mathrm{~nm}$, which is more than a thousand times smaller than the diameter of a human hair and slightly larger than the size of one atom. By now, a number of nanoelements suitable for use in nanosensors have been developed. These include Carbon Nanotubes (CNT), nanowires based on semiconductor materials, metals, dielectrics, high-temperature oxides, nitrides, etc. [4, 27, 28].

There are different types of nanosensors that measure various physical parameters. For example, pressure sensors are widely used in vehicles for engine control systems to improve the vehicle fuel efficiency (e.g., monitoring manifold absolute pressure, fuel injection), to measure fuel tank, common rail and oil reservoir pressure. Moreover, pressure sensors are necessary for the brake system, adaptive suspension, air conditioning, tire pressure monitoring, airbag control. These sensors work on various principles like electro-optics, electromagnetic and piezoelectricity.

In particular, Maddipatla D. et al. [29] developed, fabricated and investigated an efficient, flexible and cost-efficient CNT-based capacitive pressure sensor. Plesco et all presented a highly sensitive piezoelectric pressure sensor based on microstructured graphene aerogel functionalized by CdS nanocrystalline thin film [30]. A piezoresistive pressure sensor (Fig. 2) with a $200 \mu \mathrm{m}$ diaphragm with silicon nanowires (SiNWs) as the sensing element was also developed by Lou et al [31]. The sensor is able to sustain the pressure above 330 psi.

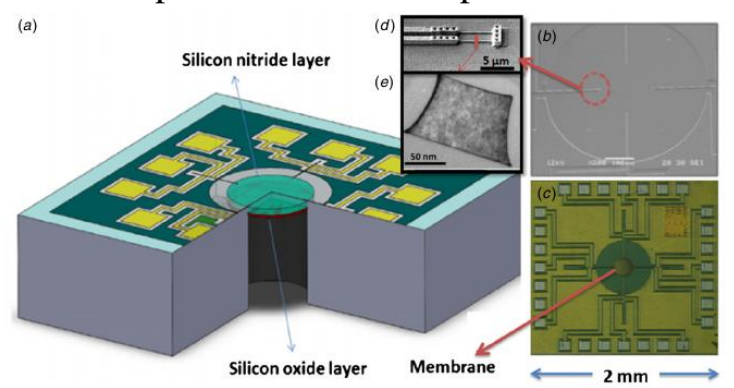

Fig. 2. (a) Schematic drawing of a pressure sensor, (b) a SEM picture of the central part of the pressure sensor, (c) an optical picture of the pressure sensor, (d) a SEM picture of a 5 m SiNW after metal deposition, and (e) a TEM picture of the SiNW [31]

Zhang (Fig. 3) also presented the sensor with silicon nanowire piezoresistors. The authors achieved a high sensitivity of $495 \mathrm{mV} / \mathrm{V} \cdot \mathrm{MPa}$ in the range of $0-100 \mathrm{kPa}$ with the maximum of $0.13 \mathrm{kPa}$ [32].

Several variants of piezoresistive pressure nanosensors were described in other reports, for instance [33-37]. Moreover, pressure 
nanosensors that work on other physical principles are also developed [38].

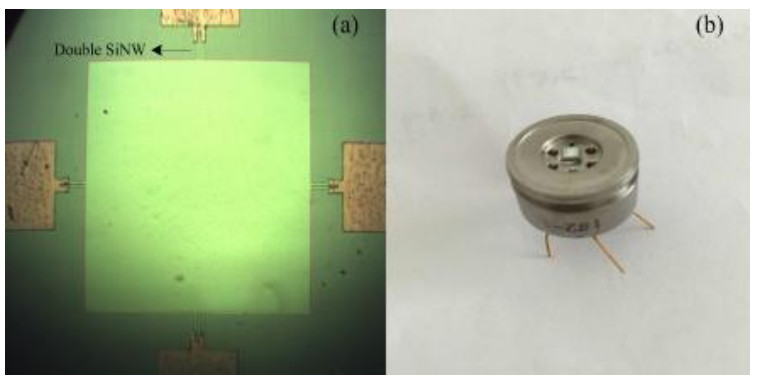

Fig. 3. (a) A photograph of the fabricated SOI pressure sensor die using double SiNW before the release; and (b) a photograph of packaged pressure sensor [32]

Other, devices, nanogenerators, have a promising potential for tire pressure monitoring, as well as for the traction coefficient determining $[26,39,40]$. The nanogenerator is a miniature device consisting of zinc oxide nanofibers, which have a well-known piezoelectric effect under the influence of low mechanical energies. These devices have a high signal-to-noise ratio, low cost, flexibility, durability, the ability to work in harsh environments, and more importantly, a nanogenerator is a source of energy.

One of the important applications of nanosensors for the automotive industry is sensors for monitoring exhaust gases [41]. The main component of the sensor is a sensitive layer placed on a solid substrate, which, in contact with the molecules of targeted gas, changes its electronic property due to the adsorption effect [28]. The components of the active layer are metal oxides and sulfides, electrically conductive polymers, and nanostructures. For example, nanocrystals of organometallic compounds of platinum exhibit high sensory activity on $\mathrm{SO}_{2}$. Gas sensors based on carbon nanotubes are also efficient [42-44]. The problem of selectivity of components of complex gas mixtures can be successfully solved by using graphene.

Exhaust gas sensors also include sensors that measure the concentration of carbon monoxide in a vehicle cabin [45].

Apart from pressure and gas sensors, the other significant types of automotive sensors are speed and acceleration sensors, position sensors, temperature sensors, and mass/air flow sensors.

The most important automotive systems are safety systems, which reduce the burden of death and injury to drivers and passengers in road traffic accidents. With this end in view, manufacturers develop both passive (e.g., air- bags) and active safety systems, such as dynamics control systems and rollover protection systems. One of the most important factors in the improvement of such safety systems is the further development of acceleration and angular rate sensors [46-48].

These sensors contain an array of nanowires with suspended silicon mass. Mechanical loading changes the electronic properties of nanowires. Various materials are used as a material for nanowires, for example, barium titanate $\left(\mathrm{BaTiO}_{3}\right)$ [49]; however, carbon modifications, in particular, graphene, are most popular [50]. Accelerometers consisting of movable and stationary electrodes made of silicon materials (Fig. 4) are also widespread [51, 52].

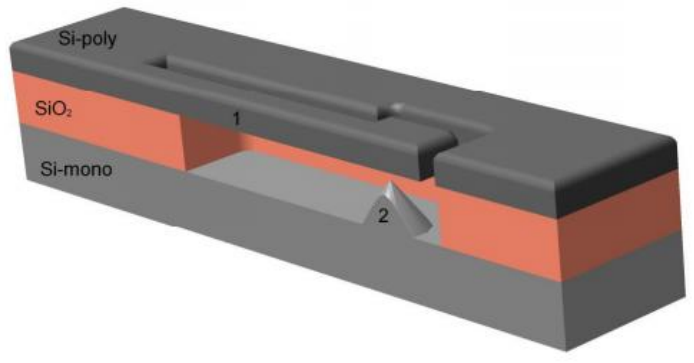

Fig. 4. Schematic representation of sensing accelerometer element based on silicon nanostructures: 1 - movable electrode; 2 - stationary electrode [51]

Most of the sensors mentioned above change some electrical parameters during the measurement. This parameter is then expedient to convert to the change frequency of the electric signal for further registration of measured data. However, as noted above, it is necessary to implement the technology of frequency signal processing, which can increase its reliability in the case of dynamic measurements using nanosensors. Nevertheless, as we can see from the above, with all the versatility of papers, devoted to automotive nanosensors, there is not a sufficient number of research devoted to improving the accuracy and reliability of frequency measurement in nanosensors. In the next section, we present the results of research [16-18], which will fill the gap in the indicated area, and their application will allow us to measure the frequency fast and accurate.

\section{Fundamentals of principle of rational approximation}

The principle of rational approximation proposed by the authors [16-18] is based on a well- 
known method in which the required frequency is determined by comparison with a given standard frequency. However, the main difference is that not the usual counting of pulses in the time sample is performed, but a particular algorithm is utilised. According to this algorithm, the crossings of both frequencies is detected. For this, two regular independent narrow pulse trains with widths $\tau$ are formed (see Fig. 5). One of the train $S_{x}$ corresponds to the unknown (desired) frequency $f_{x}$ and the second one $S_{0}$ to the given standard frequency $f_{0}$. These trains are compared for pulses coincidence and when the pulses coincide, a coincidence pulse train $S_{x} \& S_{0}$ is generated.

The first coincidence pulse of the train $S_{x} \& S_{0}$ is a trigger to start counting pulses $P$ and $Q$ of the trains $S_{x}$ and $S_{0}$ respectively. The second coincidence pulse of the train $S_{x} \& S_{0}$ is the stop pulse (Fig. 5). This second coincidence pulse stops the $P$ and $Q$ counting and their values are used for the unknown frequency $f_{x}$ calculation. The corresponding block diagram of the circuit, providing the frequency $f_{x}$ measurement, is shown in Fig. 8. The "Coincidence detector" block compares the trains of pulses $S_{x}$ and $S_{0}$ for coincidence. Precisely at the moment of pulses coincidence, the first pulse of the train $S_{x} \& S_{0}$ is formed which starts counting the pulses of the trains $S_{x}$ and $S_{0}$ with the "P Counter" and "Q Counter". The next coincidence stops the pulses counting. The microcontroller unit MCU controls this process and calculates the frequency $f_{x}$ by multiplying the given standard frequency $f_{0}$ by the ratio of the sum of pulses $P$ and $Q$ :

$$
f_{x}=f_{0} \frac{\sum_{m} P_{n}}{\sum_{m} Q_{n}},
$$

where $n$ is the number of pulses coincidence; $P_{n}$ and $Q_{n}$ are the number of counted pulses from the trains $S_{x}$ and $S_{0}$ that occur between adjacent coincidences $n$ and $n+1$.

Besides, MCU stores in its memory the numbers $P$ and $Q$ of impulses from the trains $S_{x}$ and $S_{0}$ counted by the "P Counter" and "Q Counter".

Consider the essence of the principle of rational approximation in more detail, again focusing on Fig. 5. We have two pulse trains $S_{x}$ and $S_{0}$ of frequencies $f_{x}$ and $f_{0}$. The periods corresponding to the frequencies are $T_{x}=1 / f_{x}$ and $T_{0}=1 / f_{0}$. The widths $\tau$ of the pulses are equal. For this, the signal with an unknown frequency needs adjusting with maintaining the original frequency.

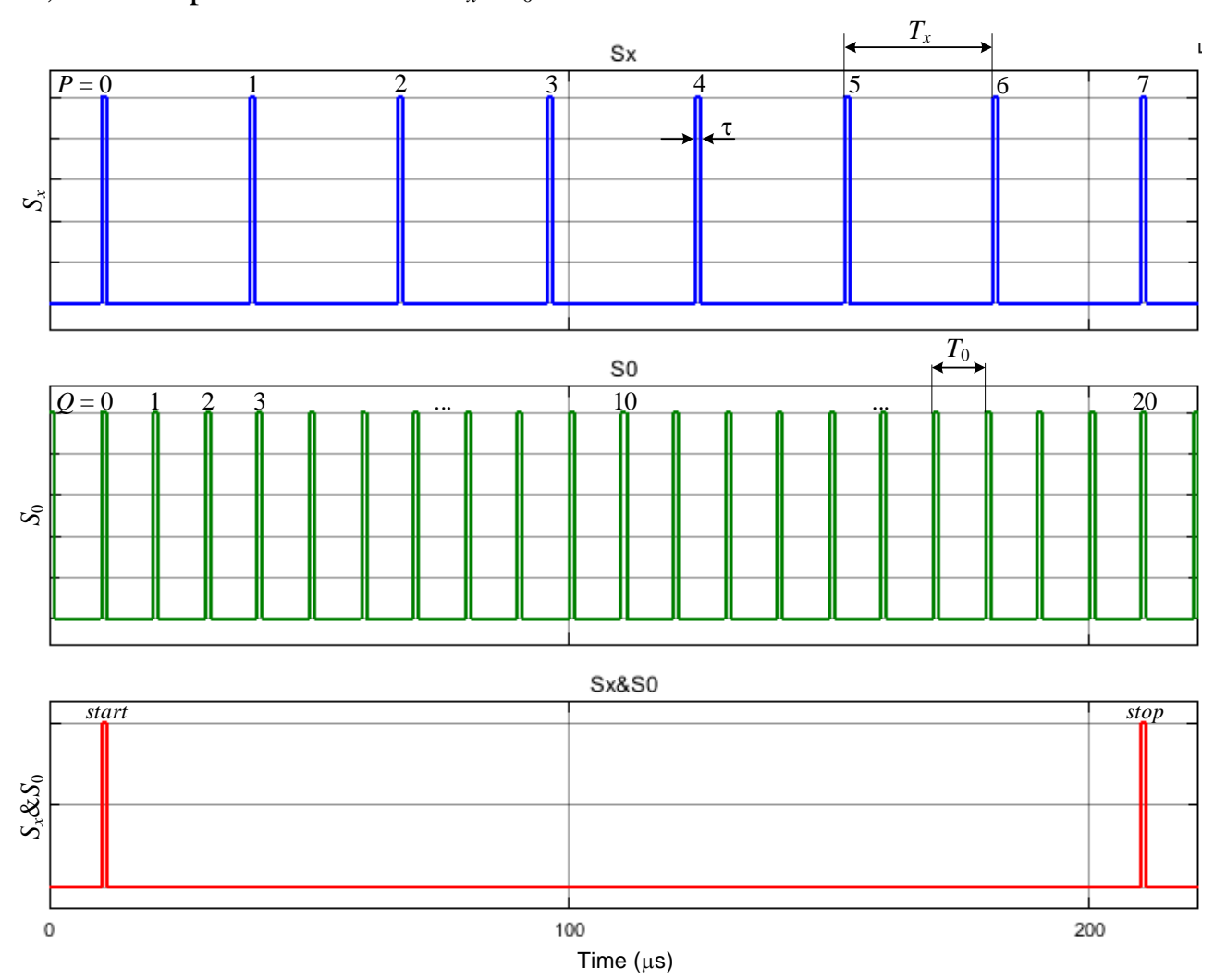

Fig. 5. Process of direct frequency comparison: geometric theory of coincidence transformation 


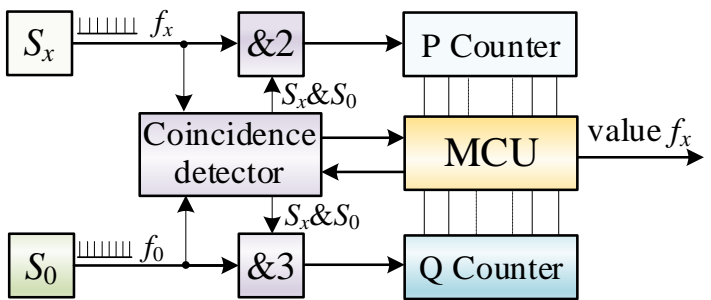

Fig. 6. Block diagram of frequency meter circuit

Denote $\Delta T$ as greatest common factor (gcf) of both periods $T_{x}$ and $T_{0} . \Delta T$ is the minimally discernible time interval and indirectly the quantum, which, as shown below, is determined by the stability of the standard frequency. It should be noted, that $\Delta T$ and the pulses widths $\tau$ are independent parameters. With the help of gcf $\Delta T$ we can write $a=T_{x} / \Delta T, b=T_{0} / \Delta T$. Hence, a common multiple is $c=T_{x} / \Delta T \times T_{0} / \Delta T$. If we denote $T_{x 0}=T_{x} T_{0} / \Delta T$, then $c=T_{x 0} / \Delta T$.

Fig. 5 shows that some pulses from the trains $S_{x}$ and $S_{0}$ coincide exactly along the time axis. In general, adjacent coincidences $n$ and $n+1$ can be either complete or partial. The first pair of these impulses $\left(P_{0}=0, Q_{0}=0\right)$ is a command to start frequency measurement by the frequency meter shown in Fig. 6. The Simulink diagram in Fig. 7 demonstrates one of the possible ways to determine this coincidence and generate the start pulse. An AND gate block fixes the coincidence and generates the start pulse of the train $S_{x} \& S_{0}$ (Fig. 8). The start pulse sets/resets the outputs Q and !Q of a JK flip-flop. The appearance of a logic "1" from the flip-flop Q output at the inputs of $\& 2$ and $\& 3$ begins counting the number of pulses $\mathrm{P}$ and $\mathrm{Q}$.

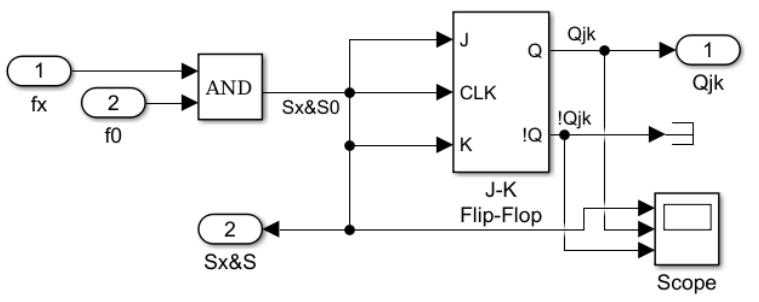

Fig. 7. Simulink diagram of the Coincidence detector

The next coincidence $\left(P_{x}=7, Q_{0}=20\right.$ in Fig. 5) generates the stop pulse which resets/sets the outputs at $\mathrm{Q}$ and !Q of the JK flip-flop (Fig. 8). The counting of pulses $P_{n}$ and $Q_{n}$ is completed and the unknown frequency $f_{x}$ is calculated using the formula (2):

$$
f_{x}=100 \frac{7}{20}=35 \mathrm{kHz} .
$$
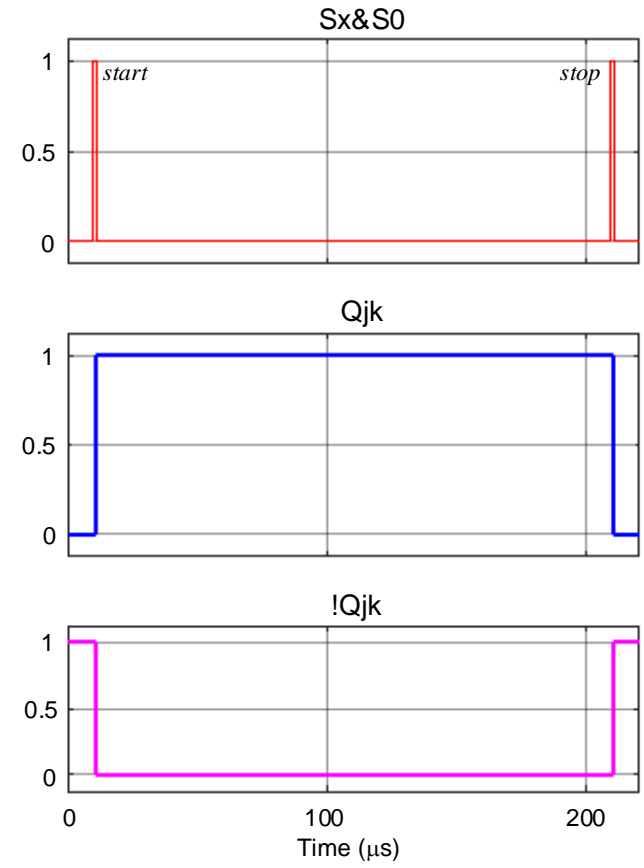

Fig. 8. Input and output signals of the JK flip-flop

Fig. 9 shows a Simulink diagram to simulate the described above example of determining the unknown frequency. The counting of pulses is performed by the "Counter P" and "Counter Q" blocks; as an example, Fig. 10 displays the contents of the "Counter P" block.

In Fig. 5 the pairs of pulses $P_{0}=0, Q_{0}=0$ and $P_{n}=7, Q_{n}=20$ completely coincident. However, between two completely coincident pairs of pulses, some of the pulses may coincide partially. These partially coinciding pulses can also be used to estimate the unknown frequency $f_{x}$.

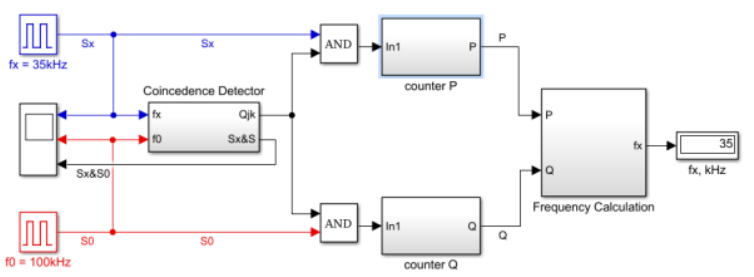

Fig. 9. Simulink diagram of the frequency counter

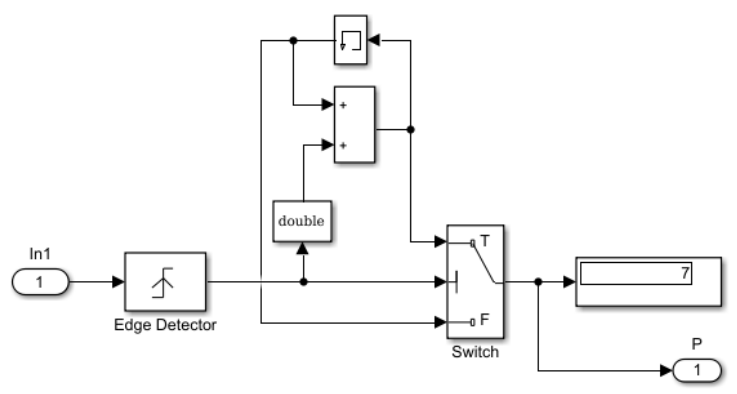

Fig. 10. Content of the block "Counter P" in Fig. 9 

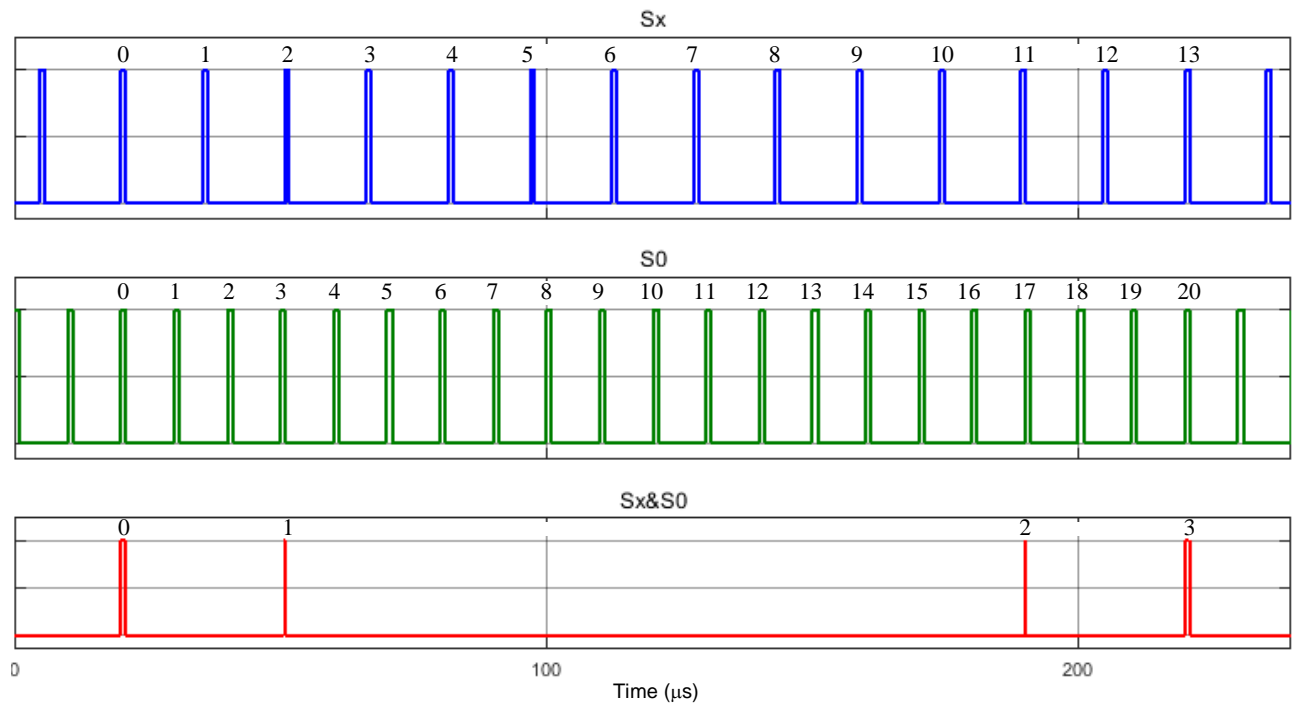

Fig. 11 . The pulse trains with partially coinciding pulses

Consider as an example the pairs of partially coinciding pulses in Fig. 11: $P_{1}=2, Q_{1}=3$, $P_{2}=11, Q_{2}=17$.

Each of the ratios

$$
\frac{P_{1}}{Q_{1}}=\frac{2}{3}, \frac{P_{2}}{Q_{2}}=\frac{11}{17}
$$

can be used for estimating the unknown frequency $f_{x}$. However, this estimation is not optimal. If we have two relations of the form (3), we can find the mediant [53]:

$$
\frac{P_{2}}{Q_{2}}<\frac{P_{1}+P_{2}}{Q_{1}+Q_{2}}<\frac{P_{1}}{Q_{1}}
$$

Thus, the rations (3) are approximants to each other and to their mediant:

$$
\frac{P_{1}+P_{2}}{Q_{1}+Q_{2}}=\frac{2+11}{3+17}=\frac{13}{20} .
$$

The mediant (4), (5) is the specific case. For the general case, we can write:

$$
\frac{\sum_{m} P_{n}}{\sum_{m} Q_{n}}(n=1,2 \ldots, m=2,3, \ldots n-1),
$$

where $n$ is the number of the ratio, and $m$ is the number of the mediant.

Expression (6) provides continuous averaging of the pulses ratio $P_{n} / Q_{n}$ during the measurement time.

Denote the ratio of frequencies as $\alpha=f_{x} / f_{0}$. Since the median (6) is closer to $\alpha$ than the fractions that form it, we can write:

$$
\frac{f_{x}}{f_{0}}=\frac{\sum_{m} P_{n}}{\sum_{m} Q_{n}}
$$

Using the approximants and their mediant we can calculate the value of unknown frequency and the systematic error of the frequency determination:

$$
f_{x m}=f \frac{\sum_{m} P_{n}}{\sum_{m} Q_{n}},
$$

where $f_{x m}$ is the approximation of unknown frequency $f_{x}$ value.

For the above example (Fig 11) equation (8) yields:

$$
f_{x m}=100 \frac{13}{20}=65 \mathrm{kHz} \text {, }
$$

which is exactly equal to the frequency fx from the sequence $S_{x}$ in Fig. 11.

However, in the general case, calculating the frequency of an unknown sequence using coinciding pulses can be accompanied by an error:

$$
\beta_{x m}=\frac{\Delta f_{x m}}{f_{x}}=\frac{1}{\sum_{m} P_{n} \times \sum_{m} Q_{n}},
$$

where $\beta_{x m}$ is the systematic error of frequency measurement.

In (5) we can chose the mediant that satisfies the following expression:

$$
0 \leq\left|T_{x} \sum_{m} P_{n}-T_{0} \sum_{m} Q_{n}\right|<\Delta T .
$$




\section{Conclusions}

Processes in automotive systems can change very fast, so the corresponding sensors have to have a high processing speed. The use of nanotechnology in automotive sensors imposes additional requirements, such as high and resolution, wide dynamic range, and noise immunity.

The analysis of nanosensors carried out in this paper showed that most of them convert the measured parameter into a change in the frequency of the output signal.

The considered method for determining the frequency allows meeting mentioned requirements. In the first place, it increases the resolution and reduces the measurement time required for a quantitative assessment of the measured parameters. It should also be noted that the error in determining the frequency is caused only by the instability of the reference frequency, which increases the measurement accuracy.

\section{References}

1. Guerrero-Ibanez J., Zeadally S. and ContrerasCastillo J. Sensor Technologies for Intelligent Transportation Systems. Sensors. 2018, vol. 18, no. 4, Art no. 1212, doi: 10.3390/s18041212.

2. Automotive Mechatronics. Bosch Professional Automotive Information, K. Reif Ed.: Springer Vieweg, 2015, p. 538.

3. Coelho M.C., Torrao G., Emami N. and Gracio J. Nanotechnology in Automotive Industry: Research Strategy and Trends for the Future-Small Objects, Big Impacts. Journal of Nanoscience and Nanotechnology. 2012, vol. 12 , no. 8, pp. 66216630, doi: 10.1166/jnn.2012.4573.

4. Madou M.J. From MEMS to Bio-MEMS and BioNEMS: Manufacturing Techniques and Applications (Fundamentals of Microfabrication and Nanotechnology, no. 3). CRC Press, 2011.

5. Asmatulu R., Nguyen P. and Asmatulu E. Nanotechnology Safety in the Automotive Industry. Nanotechnology Safety, 2013, pp. 57-72.

6. Lombardi M.A. Fundamentals of time and frequency. Mechatronic Systems, Sensors, and Actuators. Fundamentals and Modeling, R. H. Bishop Ed.: CRC Press, 2013, ch. 17.

7. Huang L., Yang H., Gao Y., Zhao L. and Liang J. Design and Implementation of a Micromechanical Silicon Resonant Accelerometer. Sensors. 2013, vol. 13, no. 11, pp. 15785-15804, doi: 10.3390/s131115785.

8. Johansson S. and Ieee. New frequency counting principle improves resolution. IEEE International Frequency Control Symposium and Exposition. Vancouver, CANADA, 2005, pp. 628-635, doi: 10.1109/freq.2005.1574007.

9. Kirianaki N.V., Yurish S.Y. and Shpak N.O., Methods of dependent count for frequency measurements. Measurement. 2001, vol. 29, no. 1, pp. 31-50, doi: 10.1016/s0263-2241(00)00026-9.
10. Zeng K.F., Ong K.G., Mungle C. and Grimes C.A. Time domain characterization of oscillating sensors: Application of frequency counting to resonance frequency determination. Review of Scientific Instruments. 2002, vol. 73, no. 12 , pp. 4375-4380, doi: 10.1063/1.1518128.

11. Wang $\mathrm{H}$. et al. A time and frequency measurement method based on delay-chain technique. 2008 IEEE International Frequency Control Symposium. 2008, pp. 484-486, doi: 10.1109/freq.2008.4623046.

12. Dehghani A., Saneei M. and Mahani A. A highresolution time-to-digital converter using a threelevel resolution. International Journal of Electronics. 2016, vol. 103, no. 8, pp. 1248-1261, doi: $10.1080 / 00207217.2015 .1092599$.

13. Tan C., Wang J.C. and Li Z.L. A frequency measurement method based on optimal multiaverage for increasing proton magnetometer measurement precision. Measurement. 2019, vol. 135, pp. 418-423, doi: 10.1016/j.measurement.2018.10.016.

14. Kia S.H., Henao H. and Capolino G.A. A highresolution frequency estimation method for threephase induction machine fault detection. Ieee Transactions on Industrial Electronics. 2007, vol. 54, no. 4, pp. 2305-2314, doi: 10.1109/tie.2007.899826.

15. Tu Y.Q. and Shen Y.L. Phase correction autocorrelation-based frequency estimation method for sinusoidal signal. Signal Processing. 2017, vol. 130, pp. 183-189, doi: 10.1016/j.sigpro.2016.06.012.

16. Sergiyenko O.Y. The mediant method for fast mass/concentration detection in nanotechnologies. International Journal of Nanotechnology. 2016, vol. 13, no. 1-3, pp. 238249, doi: 10.1504/ijnt.2016.074537.

17. Murrieta-Rico F.N. et al. Optimization of pulse width for frequency measurement by the method of rational approximations principle. Measurement. 2018, vol. 125, pp. 463-470, doi: 10.1016/j.measurement.2018.05.008.

18. Murrieta-Rico F.N. et al. Pulse width influence in fast frequency measurements using rational approximations. Measurement. 2016, vol. 86, pp. 67-78,

doi: 10.1016/j.measurement.2016.02.032.

19. Presting H. and Konig U. Future nanotechnology developments for automotive applications. Materials Science \& Engineering C-Biomimetic and Supramolecular Systems. 2003, vol. 23, no. 6-8, pp. 737-741, doi: 10.1016/j.msec.2003.09.120.

20. Mohseni M., Ramezanzadeh B., Yari H. and Moazzami Gudarzi M. The Role of Nanotechnology in Automotive Industries. New Advances in Vehicular Technology and Automotive Engineering, Joao P.C. and Joao E.R. Eds.: Intech, 2012, ch. 1.

21. Mathew J., Joy J. and George S.C. Potential applications of nanotechnology in transportation: 
A review. Journal of King Saud University Science. 2019, vol. 31, no. 4, pp. 586-594, doi: 10.1016/j.jksus.2018.03.015.

22. Bhatt G., Manoharan K., Chauhan P.S. and Bhattacharya S. MEMS Sensors for Automotive Applications: A Review. Sensors for Automotive and Aerospace Applications. Energy, Environment, and Sustainability, Bhattacharya S., Agarwal A., Prakash O. and Singh S. Eds. Singapore: Springer, 2019, pp. 223-239.

23. Mohankumar P., Ajayan J., Yasodharan R., Devendran P. and Sambasivam R. A review of micromachined sensors for automotive applications. Measurement. 2019, vol. 140, pp. 305-322, doi: 10.1016/j.measurement.2019.03.064.

24. Marek J. Automotive MEMS sensors - Trends and applications. Proceedings of 2011 International Symposium on VLSI Technology, Systems and Applications. 2011, pp. 1-2, doi: 10.1109/VTSA.2011.5872208.

25. Uzawa R., Nishikawa M. and Tanaka T. 6.5 thGeneration Automotive Pressure Sensors. Fuji Electric Review. 2017, vol. 63, no. 4, pp. 232236.

26. Askari H., Hashemi E., Khajepour A., Khamesee M.B. and Wang Z.L. Towards self-powered sensing using nanogenerators for automotive systems. Nano Energy. 2018, vol. 53, pp. 10031019, doi: 10.1016/j.nanoen.2018.09.032.

27. Meyyappan M., Li Jing, Li Jun and Cassell A. Nanotechnology: An Overview and Integration with MEMS. 19th IEEE International Conference on Micro Electro Mechanical Systems. 2006, pp. 1-3, doi: 10.1109/MEMSYS.2006.1627721.

28. Khanna V.K., Khanna V.K., Ed. Nanosensors: Physical, Chemical, and Biological, 2nd ed. CRC Press, 2021, p. 578.

29. Maddipatla D., Narakathu B.B., Ali M.M., Chlaihawi A.A. and Atashbar M.Z. Development of a novel carbon nanotube based printed and flexible pressure sensor. 2017 IEEE Sensors Applications Symposium (SAS). 2017, pp. 1-4, doi: 10.1109/SAS.2017.7894034.

30. Plesco I. et al. Flexible pressure sensor based on graphene aerogel microstructures functionalized with $\mathrm{CdS}$ nanocrystalline thin film. Superlattices and Microstructures. 2018, vol. 117, pp. 418422, doi: 10.1016/j.spmi.2018.03.064.

31. Lou L., Zhang S., Park W.-T., Tsai J.M., Kwong D.-L. and Lee C. Optimization of NEMS pressure sensors with a multilayered diaphragm using silicon nanowires as piezoresistive sensing elements. Journal of Micromechanics and Microengineering. 2012, vol. 22, no. 5, Art no. 055012, doi: 10.1088/0960-1317/22/5/055012.

32. Zhang J., Zhao Y., Ge Y., Li M., Yang L. and Mao X. Design Optimization and Fabrication of High-Sensitivity SOI Pressure Sensors with High Signal-to-Noise Ratios Based on Silicon Nanowire Piezoresistors. Micromachines. 2016, vol. 7 , no. 10, Art no. 187, doi: 10.3390/mi7100187.

33. Vajjaramatti A., Kirankumar B.B. and Ashokkumar M. Design, Simulation and Analysis of NEMS based Piezoresistive Pressure Sensor. International Journal of Engineering Research \& Technology. 2020, vol. 9, no. 7, p. 4, doi: 10.17577/IJERTV9IS070342.

34. Chen M. et al. An ultrahigh resolution pressure sensor based on percolative metal nanoparticle arrays. Nature Communications. 2019, vol. 10, Art no. 4024, doi: 10.1038/s41467-019-12030-x.

35. Milne J.S., Rowe A.C.H., Arscott S. and Renner C. Giant Piezoresistance Effects in Silicon Nanowires and Microwires. Physical Review Letters. 2010, vol. 105, no. 22, Art no. 226802, doi: 10.1103/PhysRevLett.105.226802.

36. Stampfer C. et al. Fabrication of single-walled carbon-nanotube-based pressure sensors. Nano Letters. 2006, vol. 6, no. 2, pp. 233-237, doi: $10.1021 / \mathrm{nl} 052171 \mathrm{~d}$.

37. Zhou J. et al. Flexible piezotronic strain sensor. Nano Letters. 2008, vol. 8, no. 9, pp. 3035-3040, doi: $10.1021 / \mathrm{nl} 802367 \mathrm{t}$.

38. Fitzpatrick M., Pechstedt R. and Lu Y. A new design of optical in-cylinder pressure sensor for automotive applications. SAE Technical Paper. 2000, Vol. 2000-01-0539, p. 10, doi: 10.4271/2000-01-0539.

39. Hu Y., Xu C., Zhang Y., Lin L., Snyder R.L. and Wang Z. L. A Nanogenerator for Energy Harvesting from a Rotating Tire and its Application as a Self-Powered Pressure/Speed Sensor. Advanced Materials. 2011, vol. 23, no. 35, pp. 4068-4071, doi: 10.1002/adma.201102067.

40. Askari H., Hashemi E., Khajepour A., Khamesee M.B. and Wang Z.L. Tire Condition Monitoring and Intelligent Tires Using Nanogenerators Based on Piezoelectric, Electromagnetic, and Triboelectric Effects. Advanced Materials Technologies. 2019, vol. 4, no. 1, Art no. 1800105, doi: 10.1002/admt.201800105.

41. Docquier N. and Candel S. Combustion control and sensors: a review. Progress in Energy and Combustion Science. 2002, vol. 28, no. 2, pp. 107-150, doi: 10.1016/s0360-1285(01)000090 .

42. Ghodrati M., Farmani A. and Mir A. Nanoscale Sensor-Based Tunneling Carbon Nanotube Transistor for Toxic Gases Detection: A FirstPrinciple Study. Ieee Sensors Journal. 2019, vol. 19, no. 17, pp. 7373-7377, doi: 10.1109/jsen.2019.2916850.

43. Moos R. A brief overview on automotive exhaust gas sensors based on electroceramics. International Journal of Applied Ceramic Technology. 2005, vol. 2, no. 5, pp. 401-413, doi: 10.1111/j.1744-7402.2005.02041.x.

44. Kishore Kumar D. et al. Metal oxide-based nanosensors for healthcare and environmental applications. Nanomaterials in Diagnostic Tools 
and Devices, Kanchi S. and Sharma D. Eds.: Elsevier. 2020, pp. 113-129.

45. Walther D., Lin L. and Pisano A. Micro- and Nano-Technologies for Automotive Sensor Research. SAE Technical Paper. 2007, vol. 200701-1012, p. 11, doi: 10.4271/2007-01-1012.

46. Young D.J., Zorman C.A. and Mehregany M. MEMS/NEMS Devices and Applications. Springer Handbook of Nanotechnology, Bhushan B. Ed. Berlin, Heidelberg: Springer Berlin Heidelberg, 2004, pp. 225-252.

47. Swingler J. MEMS for passenger safety in automotive vehicles. MEMS for Automotive and Aerospace Applications, Kraft M. and White N.M. Eds.: Woodhead Publishing, 2013, pp. 3-28.

48. Reze M. and Osajda M. MEMS sensors for automotive vehicle stability control applications. Mems for Automotive and Aerospace Applications. 2013, no. 32, pp. 29-53, doi: 10.1533/9780857096487.1.29.

49. Koka A. and Sodano H.A. High-sensitivity accelerometer composed of ultra-long vertically aligned barium titanate nanowire arrays. Nature Communications. 2013, vol. 4, Art no. 2682, doi: $10.1038 /$ ncomms 3682 .

50. Fan X. et al. Graphene ribbons with suspended masses as transducers in ultra-small nanoelectromechanical accelerometers. Nature Electronics. 2019, vol. 2, no. 9, pp. 394-404, doi: 10.1038/s41928-019-0287-1.

51. Druzhynin A., Kogut I., Khoverko Y. and Golota V. Accelerometer sensing element based on nanostructured silicon. Computational Problems of Electrical Engineering. 2013, vol. 3, no. 1, pp. $11-15$.

52. Ollier E. et al. NEMS devices for accelerometers compatible with thin SOI technology. $2^{\text {nd }} I E E E$ International Conference of Nano/Micro Engineered and Molecular Systems. 2007, pp. 180-185, doi: 10.1109/NEMS.2007.352257.

53. Carmichael R.D. The Theory of Numbers and Diophantine Analysis. Dover Publications, 2004.

Gurko A.G., Professor, Dr. of Sc, Automation and Computer-Integrated Technologies Department, gurko@khadi.kharkov.ua. ORCID: 0000-0001-99058584. Kharkiv National Automobile and Highway University, 25, Yaroslava Mudrogo str., Kharkiv, 61002, Ukraine.

Sergiyenko O.Yu., Associate Professor, Dr. of Sc, Applied Physics Department of the Engineering Institute of Autonomous University of Baja California, Mexico, srgnk@uabc.edu.mx. ORCID: 00000003-4270-6872. Blvd. Benito Juarez y Calle de la Normal, s/n, Col. Insurgentes Este, 21280, Mexicali, Baja California, Mexico.
Метод визначення частоти для автомобільних нанодатчиків

Анотація. Актуальність. Сучасний автомобіль є складною мехатронною системою, що містить механічні та електронні компоненти, з'єднані єдиною мережею датчиків. Значна частина перспективних і наявних автомобільних датчиків на основі нанотехнологій. Проте нанодатчики мають деякі суттєві відмінності від традиційних, наприклад, менший поріг чутливості та високі динамічні характеристики. Оскільки переважна кількість автомобільних нанодатчиків перетворює зміну вимірюваного параметра на зміну частоти електричного сигналу, то актуальним $\epsilon$ завдання використання нових методів визначення иієї частоти, та як класичні методи не дозволяють реєструвати частоту одночасно швидко й точно. Мета. Забезпечення швидкості та точності вимірювань параметрів автомобільними нанодатчиками за рахунок використання нового методу визначення частоти сигналу. Метод. Запропоновано для забезпечення швидкості та точності вимірювань сучасними автомобільними нанодатчиками використовувати метод визначення частоти сигналу, щчо запропонований авторами в попередніх роботах. Результати. Проведений аналіз нанодатчиків показав, щө більшість із них перетворює вимірюваний параметр y зміну частоти вихідного сигналу. Наведено основні положення та приклади використання методу визначення частоти на основі раціональної апроксимації; виконано аналіз точності методу, запропоновано його технічну реалізацію. Висновки. Запропонований метод визначення частоти дозволяє забезпечити виконання вимог до автомобільних датчиків: високу швидкість вимірювання, низький поріг чутливості, а також високу точність за рахунок того, що помилка визначення частоти викликана лише нестабільністю еталонної частоти, та знижуватиметься 3 удосконаленням відповідних технічних засобів.

Ключові слова: автомобільні нанодатчики, вимірювання частоти, метод раціональної апроксимачіï.

Гурко Олександр Геннадійович, д.т.н., проф. каф. автоматизації та комп'ютерно-інтегрованих технологій, gurko@khadi.kharkov.ua. ORCID: 00000001-9905-8584.

Харківський національний автомобільнодорожній університет, 61002, Україна, м. Харків, вул. Ярослава Мудрого, 25.

Сергіснко Олег Юрійович, д.т.н., доцент, завідувач відділу прикладної фізики інституту Інженерії Автономного університету Нижня Каліфорнія, srgnk@uabc.edu.mx. ORCID: 00000003-4270-6872. 